\title{
Evaluation of the Neurotoxicity of the Polyethylene Glycol Hydrogel Dural Sealant
}

\author{
Polietilen Glikol Hidrojel Dural Bariyer Nörotoksisitesinin \\ Değerlendirilmesi
}

Bulent BAKAR ${ }^{1}$, Emine Arzu KOSE ${ }^{2}$, Mahi BALCI ${ }^{3}$, Pinar ATASOY ${ }^{3}$, Bahram SARKARATI ${ }^{4}$, Aslihan ALHAN 5 , Kamer KILINC ${ }^{4}$, Ismail Semih KESKIL ${ }^{1}$

${ }^{1}$ Kirikkale University, Faculty of Medicine, Department of Neurosurgery, Kirikkale, Turkey.

${ }^{2}$ Kirikkale University, Faculty of Medicine, Department of Anaestesiology and Reanimation, Kirikkale, Turkey

${ }^{3}$ Kirikkale University, Faculty of Medicine, Department of Pathology, Kirikkale, Turkey

${ }^{4}$ Hacettepe University, Faculty of Medicine, Department of Biochemistry, Ankara, Turkey.

${ }^{5}$ Ufuk University, Faculty of Arts and Sciences, Department of Statistics, Ankara, Turkey.

Correspondence address: Bulent BAKAR / E-mail: bulentbanrs@yahoo.com

\begin{abstract}
AIM: Although polyethylene glycol (PEG) is a neutral, biocompatible hydrophilic polymer recognized for its lack of interaction with biological barrier, its neurotoxicity has not been clearly identified in neurosurgery. This study is constructed to evaluate the possible neurotoxicity of a PEG hydrogel dural sealant.

MATERIAL and METHODS: After a burrhole was opened in the left parietal bone of the twenty five Wistar albino rats, the dura mater and cerebral cortex were incised and the experimental material (activated polyethylene glycol and polyethylene imine) was sprayed into the burrhole. Then brain tissues were harvested for histopathological and biochemical studies at 72 hours to investigate the acute stage changes and on 15 th day to evaluate the chronic stage changes.

RESULTS: There were statistically significant differences among the groups regarding the comparison of the values of the PMNL cell infiltration grades, gliosis and congestion in both acute and chronic stages. However, the values of the MNL cell infiltration grades, edema and fibrin formation, lipid peroxidation levels of harvested brain tissues were similar in all groups.

CONCLUSION: Although this study did not present the detailed histopathological and biochemical evaluation results, it indicated that the application of the PEG-based hydrogel sealant was not associated with neurotoxicity, delayed healing, or degenerative changes.
\end{abstract}

KEYWORDS: Polyethylene glycol, Hydrogel, Dural sealant, Neurotoxicity

öz

AMAÇ: Polietilen glikol (PEG) nötral ve vücut dokuları ile uyumlu hidrofilik karakterde bir polimer olmasına ve biyolojik bariyer olarak klinikte birçok alanda kullanılmasına rağmen nöroşirürji alanında dural bariyer olarak henüz yeni kullanılmaya başlanmış olup nörotoksik etkileri hakkında yeterli veri bulunmamaktadır. Bu çalışma, bu etkilerin bir kısmını gösterebilmek amacıyla planlanmıştır.

YÖNTEM ve GEREÇLER: Yirmi beş adet Wistar albino ratın sol parietal kemiğinde delik (burrhole) açılıp dura ve pia materleri geçilerek serebral kortekslerinde zedelenme oluşturuldu ve bazı hayvanların serebral korteksleri üzerine deneysel materyal (aktive olmuş polietilen glikol ve polietilen imine) sıkıldı. Takiben 72 saat sonunda akut dönem etkileri ve 15 gün sonunda kronik dönem etkileri incelemek amacıyla deneklerin beyin dokuları çıkarıldı ve histopatolojik ve biyokimyasal incelemeye tabi tutuldu.

BULGULAR: Deney grupları arasında polimorfonükleer hücre infiltrasyonu düzeyleri, gliozis ve konjesyon açısından akut ve kronik dönemler arasında istatistiksel olarak belirgin fark saptandı. Ancak mononükleer hücre infiltrasyon düzeyleri, ödem, fibrin formasyonu ve beyin lipid peroksidasyon düzeyleri açısından gruplar arasında belirgin istatistiksel farklılık bulunmadı.

SONUÇ: Her ne kadar bu çalışma ayrıntılı ve ileri düzey histopatolojik ve biyokimyasal inceleme sonuçlarını içermiyor olsa da, çalışma sonunda PEG kökenli hidrojel dural bariyerin nörotoksik etkilerinin olmadığı, iyileşme süresini etkilemediği ve dejeneratif değişikliklere yol açmadığı sonucuna varılmıştır.

ANAHTAR SÖZCÜKLER: Polietilen glikol, Hidrojel, Dural bariyer, Nörotoksisite 


\section{INTRODUCTION}

Neurosurgeons have reported that the dura should be repaired carefully after craniotomy to avoid complications (such as meningitis, encephalitis, poor wound healing, low-pressure headaches, arachnoiditis, chronic pain, and pseudomeningoceles) related to postoperative cerebrospinal fluid (CSF) leakage $(2,6,11)$. Tissue adhesives such as fibrin glue, collagen-based compounds, hemostatic agents, fibrin sealants, and cyanoacrylates are common adjuncts in surgical practice $(2,3,6,8)$. Several polyethylene glycol (PEG)-based hydrogel products have been approved as vascular or lung air leak sealants; and as adhesion inhibitors in abdominal or pelvic surgery $(2,10)$. Recently, to reduce the complications related to CSF leakage, and provide a more definite sealing of sutured dura, PEG-based hydrogel dural sealants have been developed (11). PEG-based hydrogels which may be more effective fluid barriers and may not compromise the healing process are newly used to render the sutured dural closure watertight in neurosurgical procedures (2). They can be constructed from a wide variety of water-interactive or watersoluble polymers; and the hydrogel is often broken down over the course of four weeks whose degredation byproducts are water-soluble and non toxic (6).

Although PEG-based hydrogel has been reported as a neutral and biocompatible hydrophilic polymer recognized for its lack of interaction with biological barrier, its neurotoxicity has not been clearly identified if it contacts directly the brain tissue which is under the dura mater in neurosurgery $(1,6,7)$. This study is constructed to evaluate the possible neurotoxicity of a PEG-based hydrogel dural sealant in the rat brain.

\section{MATERIAL and METHODS}

\section{Materials:}

Activated polyethylene glycol and polyethylene imine mixture (the product called Adherus ${ }^{\mathrm{TM}}$ Dural Sealant was purchased from HyperBranch Medical Technology, Durham, N.C.) was used in this study. The sealant is provided with two syringes containing a PEG diluent and a polyethylene imine solution, a vial containing end-modified PEG powder and a spraying device (Figure 1C). To prepare the sealant, the diluent is injected into the powder vial, and the dissolved PEG/ dye combination is drawn into the diluent syringe. These solutions are simultaneously sprayed on the dura mater, where they polymerize to form an adherent and flexible hydrogel sealant.

Anaesthesia was performed with intraperitoneal administration of $40 \mathrm{mg} / \mathrm{kg}$ ketamine $\mathrm{HCl}$ (Ketalar; Pfizer Inc, USA) and $5 \mathrm{mg} / \mathrm{kg}$ xylazine $\mathrm{HCl}$ (Rompun \%2; Bayer HealthCare AG, Germany).

In this study, twenty-five Wistar albino rats of $250-350 \mathrm{~g}$ weight were used, which were randomly divided into two main groups used for the acute stage investigation ( 72 hours after the spraying of experimental material) and chronic stage investigation (15 days after the spraying of experimental material).
The acute stage group was randomly divided into two subgroups listed as below:

- CONTROL-A group (received no chemical material; n: 5)

- PEG-A group (received dural sealant; n: 8)

The chronic stage group was randomly divided into two subgroups listed as below:

- CONTROL-C group (received no chemical material; n: 5)

- PEG-C group (received dural sealant; $\mathrm{n}: 7$ )

\section{Methods:}

This experimental study was performed in accordance with the guidelines for the use of laboratory animal subjects in research set by the Ethical Committee of Kırıkkale University (Date: Feb 11 ${ }^{\text {th }}, 2011$; number: 11).

A burrhole was performed to the left parietal bone in about 5 milimeter in diameter, and the dura mater was incised and then a lesion was created in the fronto-hippocampal cortex under the burrhole (Figure 1A). After making the cortical lesion, except those of the control groups animals $(n: 10)$, the experimental material was sprayed into the burrhole before the closure of the surgical incision (Figure 1B, C). After this procedure, all rats were removed from sedational anaesthesia spontaneously under the blanket. Then they were kept at normal room temperature. Seventy two hours later, all animals which were selected for acute stage evaluation, and 15 days later the remaining animals which were selected for chronic stage evaluation were re-sedated with injection of the intraperitoneal ketamine $\mathrm{HCl}$ and xylazine $\mathrm{HCl}$. After sedatization, air embolization through the intracardiac route was performed for sacrification. First cranial incisions of the animals were re-opened, and then they were decapitated. The brain tissues were immediately harvested for future biochemical and histopathological examinations (Figure 1D). For biochemical examination, the neural tissue specimens obtained from the anterior half side of the cerebral lesion were stored at $-30^{\circ} \mathrm{C}$ at dry air; and for histopathological examination, the neural tissue specimens that those of the other half side of the brain lesion were stored in $10 \%$ buffered formaldehyde solution at room temperature.

\section{Specimen Analysis:}

Biochemical analyses were performed by thiobarbituric acid application, and then at $532 \mathrm{~nm}$, spectrophotometry (Shimadzu ${ }^{\oplus}$ UV-120-02 spectrophotometry) was used for obtaining the results of the lipid peroxidation levels in volumes of nanomoles per gram of wet tissue (5). All specimens were evaluated by two experienced biochemist blinded to the animal groups, and experimental material.

For histopathological examination, all tissue samples were fixed at $10 \%$ buffered formaldehyde and processed according to routine light microscopic tissue processing technique. 


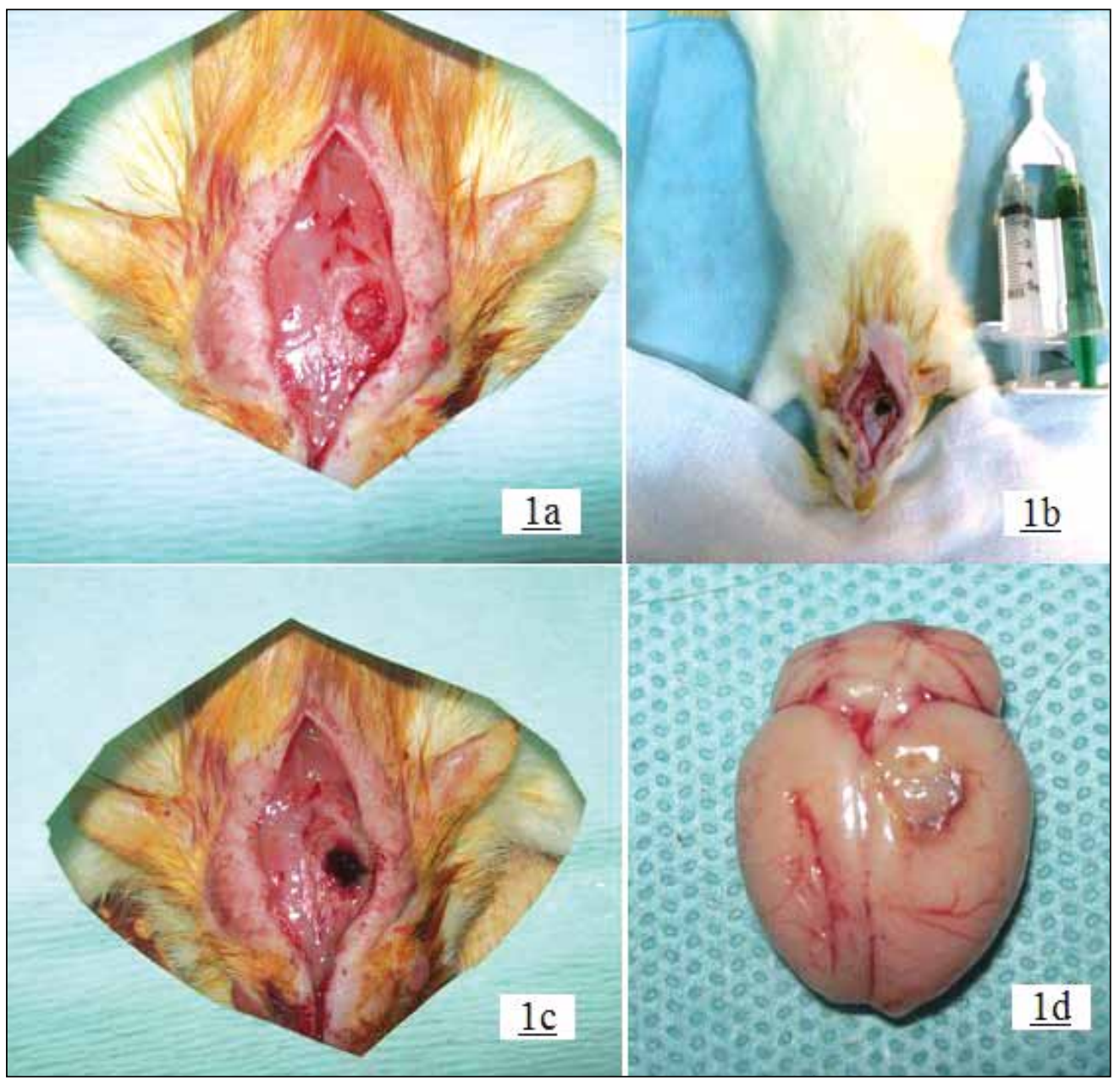

Figure 1: Figures demonstrate (A) a burrhole performed to the left parietal bone, (B, C) the experimental material sprayed into the burrhole, and (D) macroscopic appearance of the cerebral cortex following administration of PEG-based hydrogel.
Serial sections of $5 \mu \mathrm{m}$ stained with haematoxylene-eosin were examined and photographed by an microscope (Leica ${ }^{\circ}$ Microsystems, Wetzlar $\mathrm{GmbH}$ ). Histopathological sections were evaluated independently by two histopathologists blinded to the groups and experimental material. Three random regions were examined and any inflammatory reaction (the polymorphonuclear (PMNL) and/or mononuclear (MNL) cell infiltration, edema, congestion, haemorrhage, fibrin formation, and gliosis) was pointed out according to the grading scales mentioned below; and the results of the two histopathologists were compared and an average was determined (Figures 2A-D, 3A-D).

Inflammatory cell infiltration was evaluated by using a scale as following:

Grade 0- no inflammatory cell infiltration into the neural tissue lesion was observed

Grade 1- only mild inflammatory cell infiltration into the neural tissue lesion was observed.

Grade 2-moderate inflammatory cell infiltration was observed

Grade 3- severe inflammatory cell infiltration was observed.

Presence of the substeps of the inflammatory reaction processes (ie. edema, congestion, haemorrhage, fibrin formation, and gliosis) was evaluated by using a scale as follows:

\section{Grade 0- no \\ Grade 1- present}

\section{Statistical Analysis:}

Because the histopathological grading results of the groups were not normally distributed and the variation was not homogenous, these results were statistically analyzed by the Chi-Square $\left(X^{2}\right)$ test. To determine the statistical differences between the groups, the Chi-Square test was performed to all grade results.

Tissue lipid peroxidation levels were normally distributed, and the variation was homogenous between all groups. Therefore, they were statistically analyzed by the One-Way Analysis of Variance (ANOVA) test. $p$ values lower than 0.05 were considered statistically significant (4).

\section{RESULTS}

\section{Neurological examination:}

All animals tolerated the surgical procedures well and were 


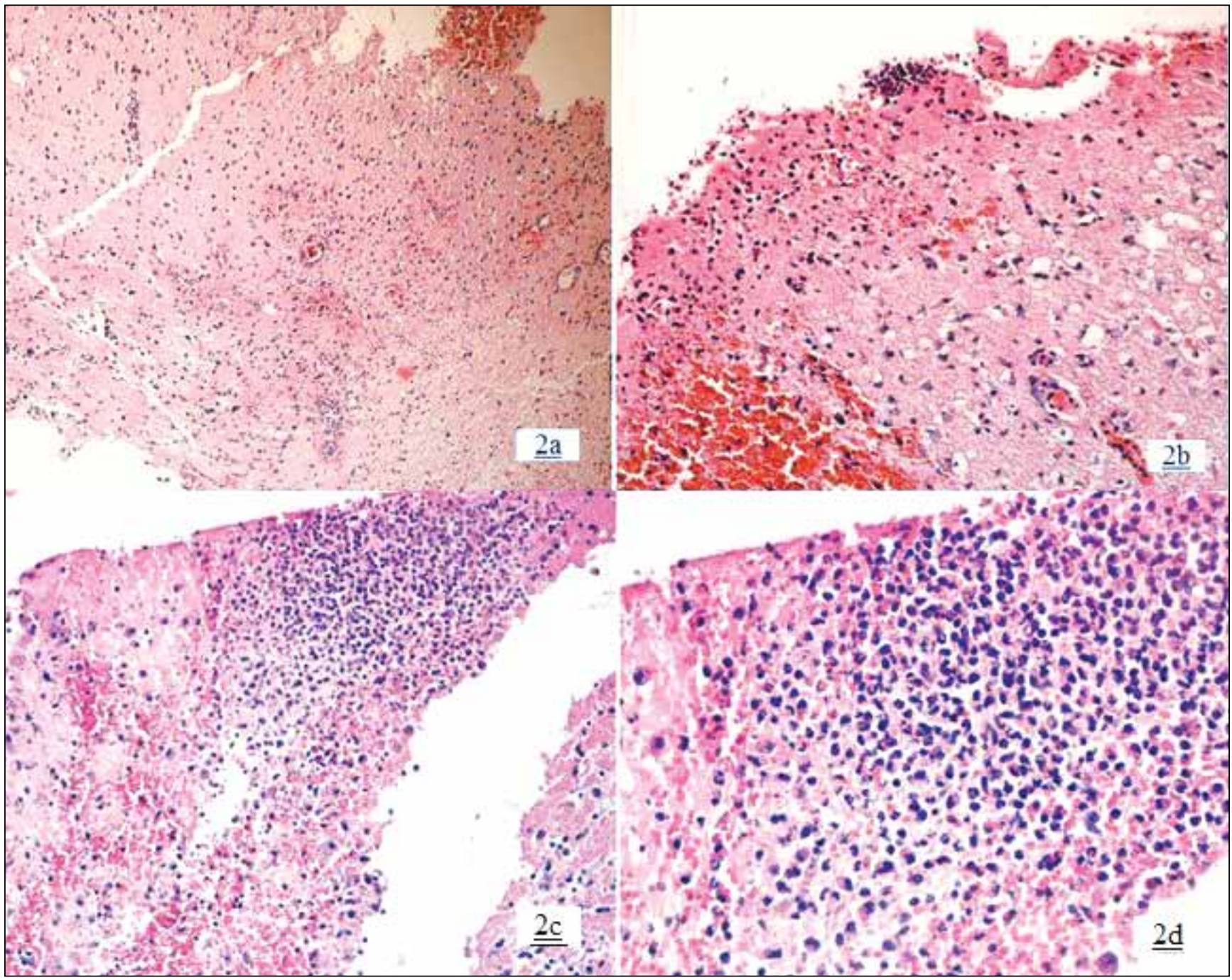

Figure 2: (A, B) The specimens of the CONTROL-A group which had oedema, vascular congestion, focal interstitial haemorrhage and PMNL cell infiltration in the fibrinous exudate. (C, D) The specimens of the PEG-A group observed oedema and haemorrhage with dense PMNL cell infiltration and accumulation of a few foamy histiocytes (HEx100, HEx200).

neurologically intact throughout the study. No seizure or behavioral abnormality was observed. All surgical incisions healed normally.

\section{Histopathological Analysis:}

\section{- PMNL cell density}

In the acute stage, one rat of in the PEG-A group had grade 0 , four rats had grade $I$, and three rats had grade II PMNL cell infiltration. One rat of the CONTROL-A group had grade 0 , two rats had grade I, one rat had grade II, and one rat had grade III PMNL cell infiltration. In the chronic stage, six rats of the PEG-C group had grade 0 , and one rat had grade I PMNL cell infiltration. Five rats of the CONTROL-C group had grade 0 PMNL cell infiltration (Figure 3A-D).

The variation in the median values of histopathological grades was statistically significant regarding the comparison of the acute and chronic stage of all groups obtained from the
Chi-Square test $\left(X^{2}=18.922 ; p<0.05\right)$ (Table I). The Chi-Square test results applied to determine the differences between the groups described that there were statistically significant differences between the PEG-A/ CONTROL-C groups $\left(X^{2}=\right.$ 9.479, $p<0.05)$, and the PEG-A/ PEG-C groups $\left(X^{2}=8.342\right.$; $p<0.05)$. However, there was no statistical difference between the CONTROL-A/ CONTROL-C, the CONTROL-A/ PEG-C and CONTROL-C/ PEG-C groups ( $p>0.05)$. These findings can recommend that the PEG-A group had more pronounced PMNL cell infiltration than the CONTROL-C, and PEG-C groups (Table II).

\section{- MNL cell density}

In the acute stage, four rats of the PEG-A group had grade 0 , three rats had grade I, and one rat had grade II MNL cell infiltration. Two rats of the CONTROL-A group had grade 0 , and three rats had grade I MNL cell infiltration. In the chronic stage, four rats of the PEG-C group had grade I, two rats had 


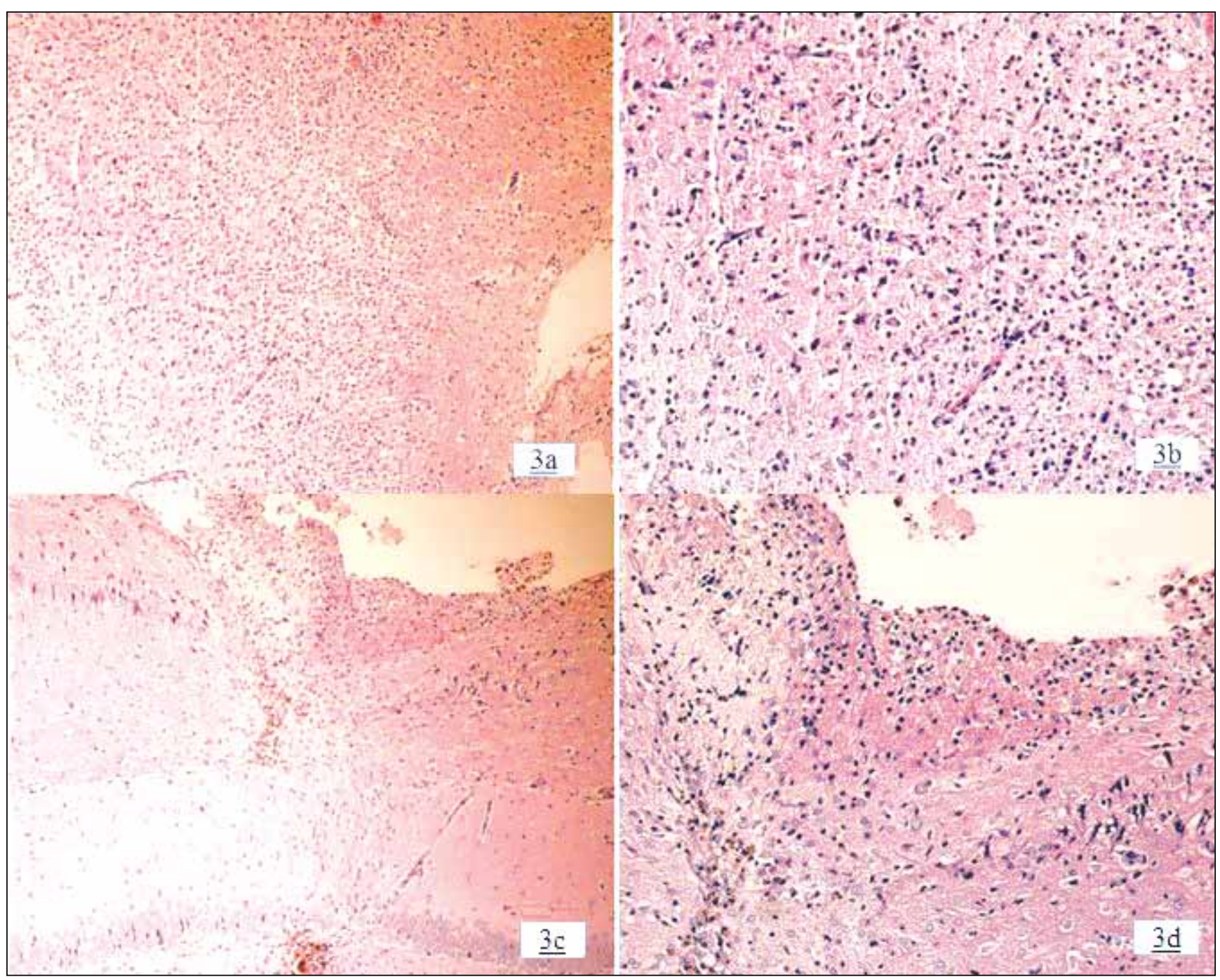

Figure 3A-D: The histopathological appearance of the CONTROL-C and PEG-C groups which had no degeneration of the neural tissue, haemorrhage, oedema or inflammatory cell infiltration, and of the chronic stage groups which had gliosis (HEx100, HEx200).

Table I: This Table Demonstrates that the Variation in the Median Values of PMNL Cell Infiltration, Gliosis and Congestion Grades Described in the Text as to be Statistically Significant Regarding the Comparison of the Acute and Chronic Stage of All Groups. ChiSquare Test, $p<0.05$

\begin{tabular}{|l|c|c|c|}
\hline & $X^{2}$ & df & $p$ \\
\hline PMNL & 18.922 & 9 & $\mathbf{0 . 0 2 6}$ \\
\hline Edema & 10.860 & 9 & 0.285 \\
\hline Gliosis & 4.171 & 3 & 0.244 \\
\hline Congestion & 17.188 & 3 & $\mathbf{0 . 0 0 1}$ \\
\hline Haemorrhage & 10.869 & 3 & $\mathbf{0 . 0 1 2}$ \\
\hline Fibrin & 6.235 & 3 & 0.101 \\
\hline
\end{tabular}

df: degrees of freedom; MNL: mononuclear; PMNL: polymorphonuclear; $\boldsymbol{X}^{2}$ : chi-square. 
Table II: This table demonstrates that PEG-A group had more pronounced PMNL cell infiltration than CONTROL-C, and PEG-C groups; and there was congestion in all acute stage group but none of those chronic stage group. This table also suggests that gliosis mainly occured in chronic stage groups. Chi-Square test, $p<0.05$

\begin{tabular}{|c|c|c|c|c|}
\hline & & $\mathbf{X}^{2}$ & df & $\mathbf{p}$ \\
\hline CONTROL-A/CONTROL-C & $\begin{array}{l}\text { PMNL } \\
\text { MNL } \\
\text { Edema } \\
\text { Gliosis } \\
\text { Congestion }\end{array}$ & $\begin{array}{c}6.667 \\
3.143 \\
0.400 \\
10.000 \\
4.286\end{array}$ & $\begin{array}{l}3 \\
2 \\
1 \\
1 \\
1\end{array}$ & $\begin{array}{l}.083 \\
.208 \\
.527 \\
.002 * \\
.038 *\end{array}$ \\
\hline CONTROL-A/PEG-A & $\begin{array}{l}\text { PMNL } \\
\text { MNL } \\
\text { Edema } \\
\text { Gliosis } \\
\text { Congestion }\end{array}$ & $\begin{array}{l}2.085 \\
1.029 \\
0.008 \\
2.438 \\
0.008\end{array}$ & $\begin{array}{l}3 \\
2 \\
1 \\
1 \\
1\end{array}$ & $\begin{array}{l}.555 \\
.598 \\
.928 \\
.118 \\
.928\end{array}$ \\
\hline CONTROL-A/PEG-C & $\begin{array}{l}\text { PMNL } \\
\text { MNL } \\
\text { Edema } \\
\text { Gliosis } \\
\text { Congestion }\end{array}$ & $\begin{array}{r}5.731 \\
4.947 \\
2.743 \\
12.000 \\
5.600\end{array}$ & $\begin{array}{l}3 \\
3 \\
1 \\
1 \\
1\end{array}$ & $\begin{array}{l}.125 \\
.176 \\
.098 \\
.001 * \\
.018 *\end{array}$ \\
\hline CONTROL-C/PEG-A & $\begin{array}{l}\text { PMNL } \\
\text { MNL } \\
\text { Edema } \\
\text { Gliosis } \\
\text { Congestion }\end{array}$ & $\begin{array}{l}9.479 \\
3.645 \\
0.627 \\
5.078 \\
5.078\end{array}$ & $\begin{array}{l}2 \\
2 \\
1 \\
1 \\
1\end{array}$ & $\begin{array}{l}.009 * \\
.162 \\
.429 \\
.024 * \\
.024 *\end{array}$ \\
\hline CONTROL-C/PEG-C & $\begin{array}{l}\text { PMNL } \\
\text { MNL } \\
\text { Edema } \\
\text { Gliosis } \\
\text { Congestion }\end{array}$ & $\begin{array}{c}0.779 \\
1.029 \\
1.029 \\
- \\
-\end{array}$ & $\begin{array}{l}1 \\
2 \\
1 \\
- \\
-\end{array}$ & $\begin{array}{l}.377 \\
.598 \\
.310 \\
1 \\
1\end{array}$ \\
\hline PEG-A/ PEG-C & $\begin{array}{l}\text { PMNL } \\
\text { MNL } \\
\text { Edema } \\
\text { Gliosis } \\
\text { Congestion }\end{array}$ & $\begin{array}{l}8.342 \\
5.434 \\
3.616 \\
6.563 \\
6.563\end{array}$ & $\begin{array}{l}2 \\
3 \\
1 \\
1 \\
1\end{array}$ & $\begin{array}{l}.015^{*} \\
.143 \\
.057 \\
.010^{*} \\
.010 *\end{array}$ \\
\hline
\end{tabular}

df: degrees of freedom; PEG: polyethylene glycol, $\mathbf{M N L}$ : mononuclear; PMNL: polymorphonuclear; $\mathbf{X}$ : chi-square.

grade II, and one rat had grade III MNL cell infiltration. Four rats of the CONTROL-C group had grade I; and one rat had grade II MNL cell infiltration (Figure 3A-D).

The variation in the median values of histopathological grades was not statistically significant regarding the comparison of the acute and chronic stage of all groups obtained from the Chi-Square test $\left(X^{2}=10.860, p>0.05\right)$ (Table I).

\section{- Edema}

In the acute stage, three rats of the PEG-A and two rats of the CONTROL-A group had no edema. However, five rats of the PEG-A and three rats of the CONTROL-A group had edema. In the chronic stage, six rats of the PEG-C and three rats of the CONTROL-C group had no edema; and one rat of the PEG-C and two rats of the CONTROL-C group had edema (Figure $3 \mathrm{~A}$ D).

The variation in the median values of histopathological grades was not statistically significant regarding the comparison of the acute and chronic stages of all groups obtained from ChiSquare test $\left(X^{2}=4.171, p>0.05\right)$ (Table I).

\section{- Congestion}

In the acute stage, three rats of the PEG-A and two rats of the CONTROL-A group had no congestion. Five rats of the PEG-A 
and three rats of the CONTROL-A group had congestion. In the chronic stage, there was no congestion in any of the rats in the PEG-C and CONTROL-C groups (Figure 3A-D).

There were statistically significant differences between the groups which were evaluated at the acute and chronic stage regarding the the median values of congestion formation $\left(X^{2}=10.869, p<0.05\right)$ (Table I). All these results analyzed with Chi-Square test showed that there were statistically significant differences between the CONTROL-A/ CONTROL-C $\left(X^{2}=4.286\right.$, $p<0.05)$, the CONTROL-A/ PEG-C $\left(X^{2}=5.600, p<0.05\right)$, the PEG-A/ CONTROL-C $\left(X^{2}=5.078, p<0.05\right)$, and the PEG-A/ PEG-C groups $\left(X^{2}=6.563, p<0.05\right)$ (Table II). These results indicated that there was congestion in all acute stage groups but none in those chronic stage groups.

\section{- Haemorrhage}

In the acute stage, three rats of the PEG-A group had no haemorrhage, and five rats had haemorrhage. Two rats of CONTROL-A group had no haemorrhage, and three rats had haemorrhage. In the chronic stage, five rats of the PEG-C group and all rats of CONTROL-C group had no haemorrhage. However, two rats of the PEG-C group had haemorrhage (Figure 3A-D).

The variation in the median values of histopathological grades was not statistically significant regarding the comparison of the acute and chronic stages of all groups obtained from ChiSquare test $\left(X^{2}=6.235, p>0.05\right)$ (Table I).

\section{- Fibrin formation}

In the acute stage, three rats of the PEG-A group and one rat of the CONTROL-A group had fibrin formation; but there was no fibrin formation in the chronic stage groups (Figure 3A-D).

The variation in the median values of histopathological grades was not statistically significant regarding the comparison of the acute and chronic stages of all groups obtained from ChiSquare test $\left(X^{2}=5.097, p>0.05\right)$ (Table I).

\section{- Gliosis}

In the acute stage, five rats of the PEG-A group had no gliosis and three rats had gliosis. Five rats of CONTROL-A group had no gliosis. In the chronic stage, all rats of the PEG-C and the CONTROL-C groups had gliosis (Figure 3A-D).

The variation in the median values of histopathological grades was statistically significant regarding the comparison of the acute and chronic stages of all groups obtained from Chi-Square test $\left(X^{2}=17.188 ; \quad p<0.001\right)$ (Table I). All these results that were analyzed with the Chi-Square test showed that there were statistically significant differences between the CONTROL-A/ CONTROL-C $\left(X^{2}=10.000, p=0.002\right)$, the CONTROL-A/ PEG-C $\left(X^{2}=12.000, p<0.001\right)$, the PEG-A/ CONTROL-C $\left(X^{2}=5.078, p<0.05\right)$, and the PEG-A/PEG-C groups $\left(X^{2}=6.563, p<0.05\right)$ (Table II).

\section{Biochemical Analysis:}

There was no statistically significant difference either between the groups that were evaluated at the acute stage or between the groups that were evaluated at the chronic stage regarding the comparison of mean values of tissue lipid peroxidation level. Furthermore, the mean values of the acute stage groups were not different from those of the chronic stage groups ( $F=1.129 ; p>0.05$ ) (Table III, Figure 4). These findings suggested that this PEG-based hydrogel did not affect the lipid peroxidation level at both stages.

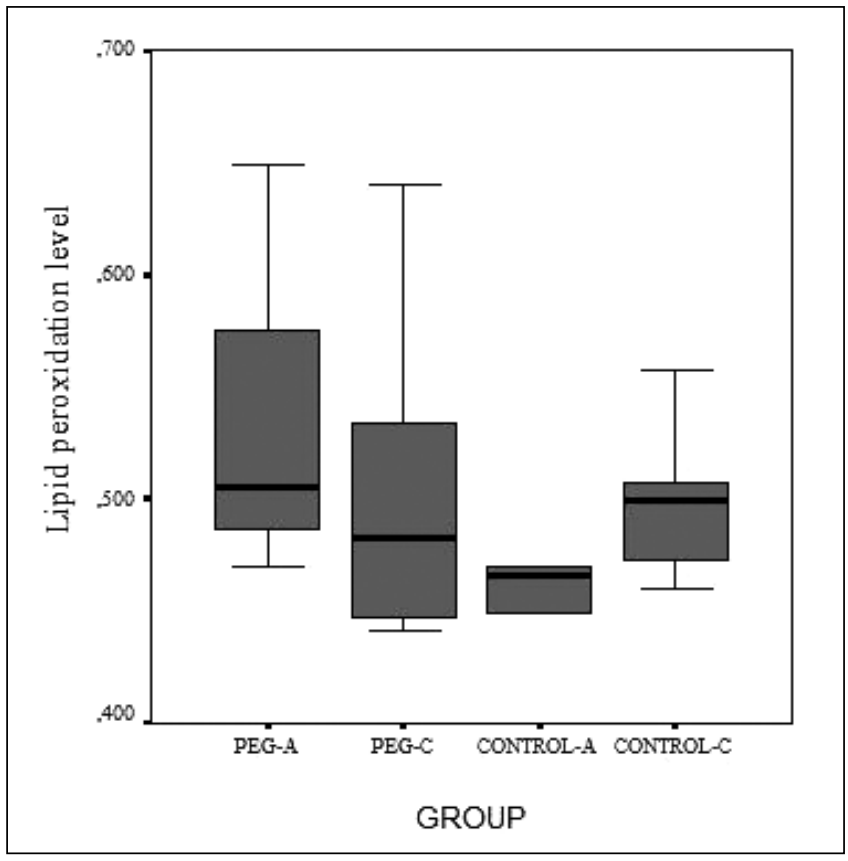

Figure 4: The mean values of the tissue lipid peroxidation level of the CONTROL-A, PEG-A, CONTROL-C, and PEG-C groups. Each error bar shows the minimum and maximum values of the lipid peroxidation level.

Table III: This Descriptive Table Shows the Mean Values of the Tissue Lipid Peroxidation Level of the CONTROL-A, PEG-A, CONTROL-C, and PEG-C Groups

\begin{tabular}{|l|c|c|c|c|}
\hline Group & Minimum & Maximum & Mean & Sd \\
\hline CONTROL-A & 0.384 & 0.564 & 0.466 & 0.06 \\
\hline PEG-A & 0.470 & 0.649 & 0.531 & 0.06 \\
\hline CONTROL-C & 0.460 & 0.557 & 0.499 & 0.04 \\
\hline PEG-C & 0.441 & 0.640 & 0.503 & 0.07 \\
\hline
\end{tabular}

PEG: polyethylene glycol, Sd: standart deviation. 


\section{DISCUSSION}

Watertight dural closure is a necessity in neurosurgical practice for preventing of the complications of the CSF leakages $(2,8,11)$. The PEG-based hydrogel sealant which is biocompatible, self-polymerizing, nontoxic, water-soluble, absorbable, flexible, and strongly adherent to tissue has been recently used to avoid these CSF leak complications; and there has been no reported sealant-related adverse events in the literature $(2,3,9,11)$.

\section{Histopathological Analysis}

Preul et al. (2003 and 2007) suggested in their study that after application the PEG-based hydrogel persists as an inert spacefiller which separates tissues, and this separation may provide the preservation of the surgical plane between the dura and surrounding tissues in acute stage animals. When compared with the control animals, they observed residual sealant and various type inflammatory cells (especially vacuolated macrophages and giant cells, lymphocytes, plasma cells, and neutrophils) within the dura mater, arachnoid, and pia mater in chronic stage animals $(6,7)$. In our study, no residual sealant was observed in any group. On the other hand, statistical results of the histopathologic evaluation demonstrated that PEG-A group had more pronounced PMNL cell infiltration than CONTROL-C and PEG-C groups. So, it can be thought that this dural sealant can stimulate the PMNL cell infiltration into the destroyed brain tissue in the acute stage of the inflammatory process in the rat. Actually, except one rat of the PEG-C group, no PMNL cell infiltration was observed in any chronic stage group. On the other hand, there was no statistical difference between the CONTROL-A and the CONTROL-C groups $(p=0.08)$, and also there was no statistically significant difference between groups regarding to PMNL cell infiltration when the CONTROL-A group compaired with the PEG-A group $(p=0.555)$. These results suggested that this statistical difference between groups can be explained by the effect of the surgical procedure but not the neurotoxic effects of the PEG-based hydrogel. In addition, our study results demonstrated that this experimental material could not stimulate MNL cell infiltration or edema and fibrin formation in the destroyed brain tissue in any stage. Also, the observation of the congestion in all acute stage groups but none in the chronic stage groups supports this hypothesis. The results of this study showed that this dural sealant does not act as a foreign body in rat neural tissue.

Preul et al. (2010) demonstrated in their laminectomy model that during the acute healing phase, PEG-based hydrogel sealant has the potential to prevent CSF leaks, and over the long term, it may facilitate re-operative access and may decrease tethering or adhesions of the dura mater (8). PEGbased hydrogel persists as an inert space-filler and separates tissues while they heal independently. This separation could provide the preservation of the surgical plane between the dura and surrounding tissues, while it blocks the inflammatory cells migration through such a PEG-based hydrogel barrier (7). In our study, appearance of the fibrin formation in only a few animals in the acute stage groups but not in those of the chronic stage groups suggested that this experimental material blocks the fibroblast migration into the injured area and decreases the level of the fibrin formation, acting as a biocompatible barrier. Moreover, this blockage may also decrease the MNL cell infiltration into the injured neural tissue in rat.

Bjugstad et al. (2010) demonstrated that inflammatory response to PEG-based hydrogels was complex depending on degradation rates of the hydrogel. They implanted PEGbased hydrogel strands into the rat brain and observed glia responses to change as a function of degradability and time. Furthermore, they did not observe immuno-rejection of the hydrogel. PEG-based hydrogel strands, when compared to sham penetrations, invoke smaller glial response during the acute stages of neuroinflammation (1). Our study results showed that gliosis occured mainly in chronic stage groups; and this finding suggested that this experimental material could not decrease this gliosis formation in the injured neural tissue in rat. Thus, this gliosis formation in the chronic stage groups can be explained with surgical procedures, and additionally, observation of no MNL cell infiltration in any of the study groups may supports this theory.

\section{Biochemical Analysis}

Although PEG-A group had more pronounced PMNL cell infiltration than CONTROL-A, CONTROL-C, and PEG-C groups, values of tissue lipid peroxidation level were not different between the acute and chronic stage groups. This result may be explained with the hypothesis of the PEG-based hydrogel as not causing free radical production from the membrane phospholipids of neural tissue at both stages. Also, histopathological evaluation results have also supported this theory with the observation of no MNL cell infiltration into the destroyed brain tissue in chronic stage. Regarding these findings, it can be hypothesized that this material did not alter the morphology and metabolism of the neural tissue.

\section{Study Limitations}

This study has some pitfalls. First, although this evaluation may pave the way for future studies on this subject, it did not contain results of more specific biochemical and histopathological analyses for other cytotoxic pathways in the acute and/or chronic stages. Additionally, this study should be supported with electron microscopic findings which can show whether there are any of the ultrastructural findings of an inflammatory response and/ or neuronal necrosis. Second, this study is far from explaining the toxic effects of PEG-based hydrogel in long term because of the selected time period. Third, this study could not demonstrate the direct toxic effects of PEG-based hydrogel on neural tissue because it has not been directly injected into the animal brain parenchyma but only sprayed on the injured brain tissue. Fourth, because this study was constructed to evaluate the possible neutoxic effects of this dural sealant, it did not include the histopathological evaluation of the dural healing processes. Fifth, in this study, 
the effects of the PEG-based hydrogel dural sealant were not compared with other materials (such as fibrin glue, gelatin sponge etc.) for their effectiveness of the dural sealing. On the other hand, our study results demonstrated that this dural sealant material is, most probably, biocompatible and nontoxic to the neural tissue in rat.

\section{CONCLUSION}

Within its limits, the present results obtained from this experimental study suggested that application of the PEGbased hydrogel dural sealant was not associated with neurotoxicity, delayed healing, or degenerative changes in neural tissue of rat.

\section{ACKNOWLEDGEMENT}

The authors would like to express their thanks and gratitude to Mrs. Zerrin Nakip for editing the manuscript; and to Mr. Erkan Kaya for his skilled assistance during the study.

\section{Conflict of Interest Statement}

The authors declare that they have no conflict of interest.

\section{REFERENCES}

1. Bjugstad KB, Lampe K, Kern DS, Mahoney M: Biocompatibility of poly(ethylene glycol)-based hydrogels in the brain: An analysis of the glial response across space and time. J Biomed Mater Res A 95: 79-91, 2010

2. Boogaarts JD, Grotenhuis JA, Bartels RH, Beems T: Use of a novel absorbable hydrogel for augmentation of dural repair: Results of a preliminary clinical study. Neurosurgery 57(1 Suppl): 146-151, 2005

3. Cosgrove GR, Delashaw JB, Grotenhuis JA, Tew JM, Van Loveren $H$, Spetzler RF, Payner T, Rosseau G, Shaffrey ME, Hopkins LN, Byrne R, Norbash A: Safety and efficacy of a novel polyethylene glycol hydrogel sealant for watertight dural repair. J Neurosurg 106: 52-58, 2007
4. Nie $\mathrm{NH}$, Hull $\mathrm{CH}$, Jenkins JG: SPSS: Statistical Package for Social Science. New York: Mc Graw Hill Inc, 1975

5. Ohkawa H, Ohishi N, Yagi K: Assay for lipid peroxides in animal tissues by thiobarbituric acid reaction. Anal Biochem 95: 351-58, 1979

6. Preul MC, Bichard WD, Spetzler RF: Toward optimal tissue sealants for neurosurgery: Use of a novel hydrogel sealant in a canine durotomy repair model. Neurosurgery 53: 1189-1199, 2003

7. Preul MC, Campbell PK, Bichard WD, Spetzler RF: Application of a hydrogel sealant improves watertight closures of duraplasty onlay grafts in a canine craniotomy model. J Neurosurg 107: 642-650, 2007

8. Preul MC, Campbell PK, Garlick DS, Spetzler RF: Application of a new hydrogel dural sealant that reduces epidural adhesion formation: Evaluation in a large animal laminectomy model. J Neurosurg Spine 12: 381-390, 2010

9. Than KD, Baird CJ, Olivi A: Polyethylene glycol hydrogel dural sealant may reduce incisional cerebrospinal fluid leak after posterior fossa surgery. Neurosurgery 63(1 Suppl 1): ONS182-187, 2008

10. Wechsler S, Fehr D, Molenberg A, Raeber G, Schense JC, Weber FE: A novel, tissue occlusive poly(ethylene glycol) hydrogel material. J Biomed Mater Res A 85: 285-292, 2008

11. Weinstein JS, Liu KC, Delashaw JB Jr, Burchiel KJ, van Loveren HR, Vale FL, Agazzi S, Greenberg MS, Smith DA, Tew J Jr: The safety and effectiveness of a dural sealant system for use with nonautologous duraplasty materials. J Neurosurg 112: 428-433, 2010 